\title{
Effect of Preliminary Irradiation of 321 Steel Substrates with High-Intense Pulsed Ion Beams on Scratch Test Results of Subsequently Deposited AlN Coatings
}

\author{
Vladislav Tarbokov ${ }^{1}$, Sergey Pavlov ${ }^{1}$, Egor Smolyanskiy ${ }^{1}$, Vladimir Uglov ${ }^{2}$, Mikhail Slobodyan ${ }^{3, *(D)}$ \\ and Gennady Remnev ${ }^{1}$ \\ 1 Laboratory of Pulse-Beam, Electric Discharge and Plasma Technologies, Tomsk Polytechnic University, 30 , \\ Lenin Prospekt, 634050 Tomsk, Russia; tarbokovv@tpu.ru (V.T.); lab.sergey@gmail.com (S.P.); \\ smolianskyea@yandex.ru (E.S.); remnev06@mail.ru (G.R.) \\ 2 Department of Solid State Physics, Belarusian State University, 4, Nezavisimosti Prospekt, \\ 220030 Minsk, Belarus; uglov@bsu.by \\ 3 Laboratory of Advanced Technologies, Tomsk Scientific Center SB RAS, 10/4, Akademicheskii Prospekt, \\ 634055 Tomsk , Russia \\ * Correspondence: s.m.s@ngs.ru
}

\section{check for}

updates

Citation: Tarbokov, V.; Pavlov, S.; Smolyanskiy, E.; Uglov, V.; Slobodyan, M.; Remnev, G. Effect of Preliminary Irradiation of 321 Steel Substrates with High-Intense Pulsed Ion Beams on Scratch Test Results of Subsequently Deposited AlN Coatings. Coatings 2021, 11, 1169. https://doi.org/10.3390/ coatings11101169

Academic Editor: Heping Li

Received: 7 September 2021

Accepted: 24 September 2021

Published: 27 September 2021

Publisher's Note: MDPI stays neutral with regard to jurisdictional claims in published maps and institutional affiliations.

Copyright: (c) 2021 by the authors. Licensee MDPI, Basel, Switzerland. This article is an open access article distributed under the terms and conditions of the Creative Commons Attribution (CC BY) license (https:// creativecommons.org/licenses/by/ $4.0 /)$.

\begin{abstract}
The paper presents the effect of irradiation of 321 steel substrates with a high-intense pulsed ion beam (HIPIB) on changes in functional properties of the surface layers and tribological characteristics of AlN coatings subsequently deposited above by the reactive magnetron sputtering method. The morphology of the modified surface layers, their microhardness and free surface energy levels are presented for different HIPIB energy densities. HIPIB irradiation of the substrates caused variations in the results of scratch tests combined with the acoustic emission signal processing. Their analysis has enabled concluding that the crack initiation threshold could be at least doubled for the studied coating/substrate system due to preliminary HIPIB irradiation. Finally, the obtained data were discussed, and future research directions were proposed.
\end{abstract}

Keywords: high-intense pulsed ion beam (HIPIB); surface modification; reactive magnetron sputtering; ceramic coating; austenitic steel

\section{Introduction}

Ceramic coatings are widely deposited on substrates from metals, alloys and steels for various applications [1-10]. In particular, considerable efforts are directed at attempts to implement them for improving the functional characteristics of austenitic stainless steels [11-25]. Key challenges for the success of these endeavors are incompatibility of microstructures and properties of the materials at the metal/ceramic interfaces [13,14,26-51], as well as residual stresse in the coatings [13,21,52-55], causing low adhesion and their delamination from the substrates. It should be noted that morphology (roughness) and other characteristics of the substrate surface layers also have a significant effect on the obtained results $[21,56,57]$. In order to solve these issues, optimization of the deposition parameters and preliminary treatment of the substrate surfaces are carried out, such as sandblasting [11,58-60], chemical etching and pickling [11,12,61], ultrasonic cleaning in various liquids [59], as well as electrical discharge [60] or laser [62,63] processing, plasma treatment [64] and irradiation with accelerated ions [65-67].

One of the effective ways to modify the surface layers of metals, alloys and steels is irradiation with a high-intense pulsed ion beam (HIPIB). In this case, a surface is cleaned, a specific microrelief is formed, and the microstructure and phase composition of a material is changed [68-80]. In addition, internal stresses in the surface layers can be varied due to different HIPIB parameters. Accordingly, matching in magnitude and sign of stresses in 
the substrates and deposited coatings enables to solve the issue of reducing their imbalance at the interface of the materials with significantly different mechanical characteristics. However, many gaps in knowledge about quantitative HIPIB irradiation results still exist, considering a huge number of possible combinations of metal substrates, types of coatings and deposition methods. The aim of these studies has been their partial filling in relation to tribological characteristics of the AlN coatings deposited on the 321 steel substrates, including preliminary HIPIB irradiated ones, by the reactive magnetron sputtering procedure. Moreover, dependences of residual stresses in trial coatings on silicon substrates were initially assessed.

\section{Materials and Methods}

Plates $15 \mathrm{~mm} \times 15 \mathrm{~mm} \times 0.5 \mathrm{~mm}$ from the 321 stainless austenitic steel $(1.2 \% \mathrm{C}$, $18 \% \mathrm{Cr}, 10 \% \mathrm{Ni}, 1 \% \mathrm{Ti}$ ) [81] were polished (including their edges) to form their flat surfaces with a roughness $R a$ of $20 \mathrm{~nm}$. Then, the samples were irradiated using a 'TEMP-4M' HIPIB accelerator (Tomsk Polytechnic University, Tomsk, Russia) [69,70,77-80] at an accelerating voltage of $200 \mathrm{kV}$, a pulse width at half maximum of $100 \mathrm{~ns}$ and energy densities of 0.6 , $1.0,1.5$ and $2.0 \mathrm{~J} / \mathrm{cm}^{2}$. The beam composition was about $85 \% \mathrm{C}^{+}$ions and $15 \%$ protons. For all modes, the number of pulses was 3 ; ion fluences were up to $2.1 \times 10^{14} \mathrm{~cm}^{-2}$. The 'Temp-4M' HIPIB accelerator and typical waveforms of accelerating voltage, diode current, and current density on a target are shown in Figure 1.

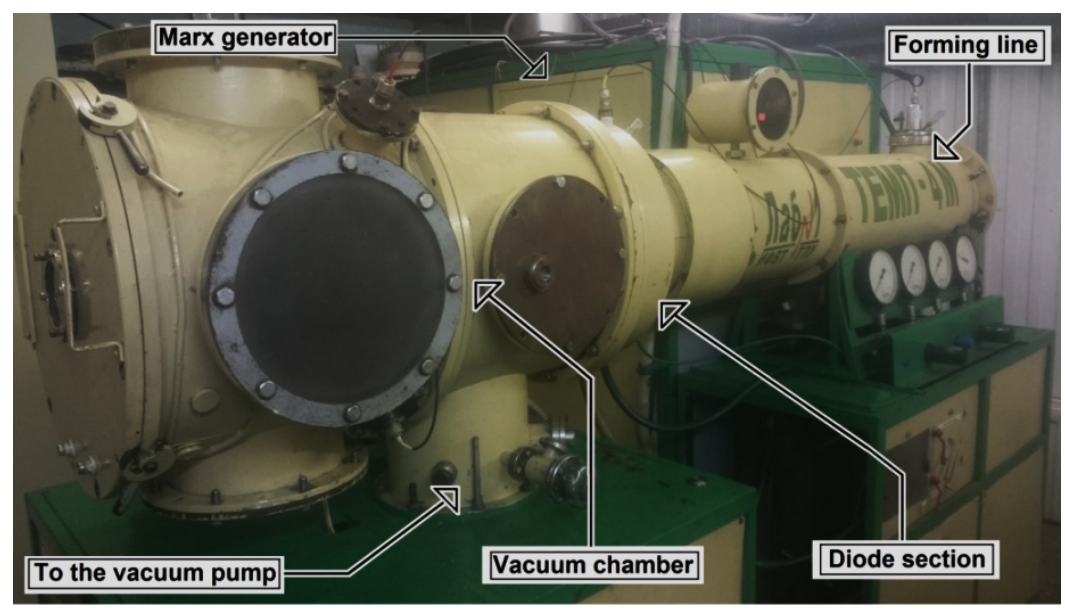

(a)

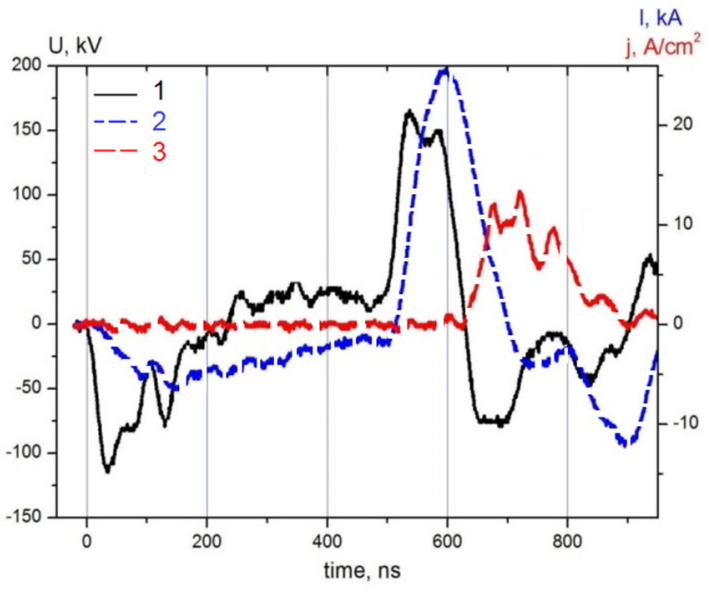

(b)

Figure 1. The 'Temp-4M' HIPIB accelerator (a) and typical waveforms (b): 1—accelerating voltage; 2-diode current; 3-current density on a target.

It should be noted that the samples were irradiated at room temperature of about $20-25{ }^{\circ} \mathrm{C}$ and did not heat up additionally. During HIPIB irradiation, the surface layers were re-melted at the energy densities of 1.5 and $2.0 \mathrm{~J} / \mathrm{cm}^{2}$, while their temperatures were below the melting points at the lower levels. The heated layer depths corresponded to the stopping range of ions within few micrometers. After one pulse, the entire sample temperature $(T)$ could be increased by about $1-3{ }^{\circ} \mathrm{C}$ according to the following relationship:

$$
\Delta T=\frac{E_{H I P I B}}{c \rho V},
$$

where $E_{\text {HIPIB }}$ was the energy densities per pulse, $c$ and $\rho$ were heat capacity and density of the 321 steel $\left(c=462 \mathrm{~J} / \mathrm{kg}^{\circ} \mathrm{C}, \rho=7670-8000 \mathrm{~kg} / \mathrm{m}^{3}\right.$ [82]), $V$ was the sample volume. Respectively, the samples could be heated by no more than $3-9{ }^{\circ} \mathrm{C}$ in three pulses.

Firstly, by analogy with the paper [35], trial AIN coatings were deposited on silicon substrates $0.38 \mathrm{~mm}$ thick by the reactive magnetron sputtering method to assess internal 
stresses. Then, the optimal mode was applied to deposit them on the HIPIB irradiated substrates from the 321 steel for evaluating tribological characteristics of the coatings. The deposition parameters were the following: a magnetron power of $1.5 \mathrm{~kW}$, the substrate-totarget distance of $150 \mathrm{~mm}$ and partial pressure of reactive gases of $0.16 \mathrm{~Pa}$. Various residual stresses were achieved due to different substrate temperatures of 120,280 , and $500{ }^{\circ} \mathrm{C}$. This prerequisite was based on the results reported in [83], according to which residual stresses in the AlN coatings changed from tensile to compressive ones as the substrate temperatures rose.

The thicknesses of the coatings were determined using an 'MII-4' microinterferometer. Average residual stresses $\left(\sigma_{f}\right)$ in the trial ones were estimated using the Stoney formula [84]:

$$
\sigma_{f}=\frac{1}{6 R} \times \frac{E_{S} \times d_{S}^{2}}{\left(1-v_{S}\right) \times d_{f}}
$$

where $E_{s}$ was the silicon elastic modulus of $169 \mathrm{GPa}$ [85]; $d_{s}$ was the substrate thickness; $R$ was the substrate bending radius; $v_{S}$ was the silicon Poisson's ratio of 0.28 [85]; $d_{f}$ was the coating thickness. The substrate bending radiuses $R$ were measured by a 'Micro Measure 3D Station (STIL)' non-contact profilometer.

X-ray diffraction analysis was performed using a 'Rigaku Ultima IV' diffractometer (Rigaku Analytical Devices, Inc., Wilmington, MA, USA) Microstresses were calculated by the Williamson-Hall method [86]. A beam incidence angle was $5^{\circ}$ to exclude the influence of the substrates.

The sample surface images were obtained using a 'JEOL 6000' (JEOL Inc., Peabody, MA, USA) scanning electron microscope (SEM).

Roughness was measured by an 'NT-MDT Integra Prima' atomic force microscope on a $100 \mu \mathrm{m}$ base (NT-MDT Spectrum Instruments, Moscow, Russia).

Vickers microhardness was determined using a 'PMT-4M' device (Matsuzawa Co.,Ltd, Akita, Japan) at a load of $40 \mathrm{~g}$. The indentation depth was 2.0-2.4 $\mu \mathrm{m}$. The measured diagonals of ten diamond indenter imprints were averaged for each HIPIB irradiation mode.

The elastic modus values of the modified layers were assessed by a 'Micro-Scratch Tester MST-S-AX-0000' facility (CSEM, Neuchatel, Switzerland).

Free surface energy (FSE) levels were found using a 'CRUSS DSA25S' contact angle meter (Kruss, Heidelberg, Gemany) by the OWRK method and 'KRÜSS ADVANCE 1.12.3.15501' software (Kruss, Heidelberg, Gemany). Water and glycerin were used as liquids. The tests were carried out within 10 min after HIPIB irradiation.

On the metal substrates, the tribological characteristics of the coatings were investigated by scratch tests combined with processing of acoustic emission (AE) signals by the 'Micro-Scratch Tester MST-S-AX- 0000 ' setup with a diamond indenter, similar to $[47,51,87-90]$. The indenter radius was $100 \mu \mathrm{m}$.

All quantitative data were statistically processed using MS Excel software (Microsoft, Redmond, WA, USA) for the most illustrative visualization of the dynamics of changes.

\section{Results}

\subsection{Characteristics of the Trial AlN Coatings on the Silicon Substrates}

Table 1 presents the deposition conditions and properties of the trial coatings on the silicon substrates. According to their lattice parameters calculated by the Rietveld method using the X-ray diffraction data, the trial coatings included the single AlN phase with the hexagonal close-packed lattice (the P63mmc space group). At the minimum studied substrate temperature, the average internal stresses were tensile of about $0.1 \mathrm{GPa}$, while they changed the sign to compressive and increased in amplitude with enhancing the temperature up to 280 and then up to $500{ }^{\circ} \mathrm{C}$. The coating deposited at $120{ }^{\circ} \mathrm{C}$ had the lowest microstrains of $0.184 \%$, while they were the highest $(0.920 \%)$ after deposition at $280^{\circ} \mathrm{C}$. This coating possessed the AlN (100) most intense diffraction peak, but it was the AlN (002) one for the other two samples. 
Table 1. The deposition conditions and properties of the trial AlN coatings.

\begin{tabular}{|c|c|c|c|c|c|c|c|}
\hline \multirow{2}{*}{ Modes } & \multirow{2}{*}{$\begin{array}{l}\text { Deposition } \\
\text { Tempera- } \\
\text { ture, }\end{array}$} & \multirow{2}{*}{$\begin{array}{c}\text { Coating } \\
\text { Thickness, } \\
\mu \mathrm{m}\end{array}$} & \multirow{2}{*}{$\begin{array}{c}\text { Substrate } \\
\text { Bending } \\
\text { Radius, } m\end{array}$} & \multirow{2}{*}{$\begin{array}{c}\text { Average Stresses in Coating, } \\
\text { GPa ('+' Is Tensile, '- }{ }^{\prime} \text { Is } \\
\text { Compressive) }\end{array}$} & \multicolumn{2}{|c|}{ Lattice Parameters } & \multirow{2}{*}{$\begin{array}{c}\text { Microstrains, } \\
\%\end{array}$} \\
\hline & & & & & $a, \mathrm{~nm}$ & $c, \mathrm{~nm}$ & \\
\hline 1 & 10 & 5.7 & 9.0 & +0.1 & $0.31140 \pm 0.00050$ & $0.49820 \pm 0.00080$ & $0.184 \pm 0.015$ \\
\hline 2 & 280 & 4.6 & -20.0 & -0.1 & $0.31170 \pm 0.00050$ & $0.50160 \pm 0.00070$ & $0.920 \pm 0.180$ \\
\hline 3 & 500 & 4.2 & -1.6 & -0.8 & $0.31237 \pm 0.00009$ & $0.49980 \pm 0.00015$ & $0.372 \pm 0.017$ \\
\hline
\end{tabular}

\subsection{Properties of the Modified Layers on the 321 Steel Substrates}

Figure 2 shows SEM images of the 321 steel surfaces (both before and after HIPIB irradiation at different modes). Their comparison enabled tracing changes in their microreliefs depending on the energy density: from the initial surfaces with clearly distinguishable grinding traces to the smooth recrystallized ones at $2.0 \mathrm{~J} / \mathrm{cm}^{2}$ through partial melting of irregularities at both levels of 0.6 and $1.0 \mathrm{~J} / \mathrm{cm}^{2}$. After HIPIB irradiation using the re-melting modes, typical microcraters were found on the sample surfaces. Thicknesses of the modified layer were not determined in these studies due to both high labor intensity and cost, but they were typically a few micrometers for such cases [91].
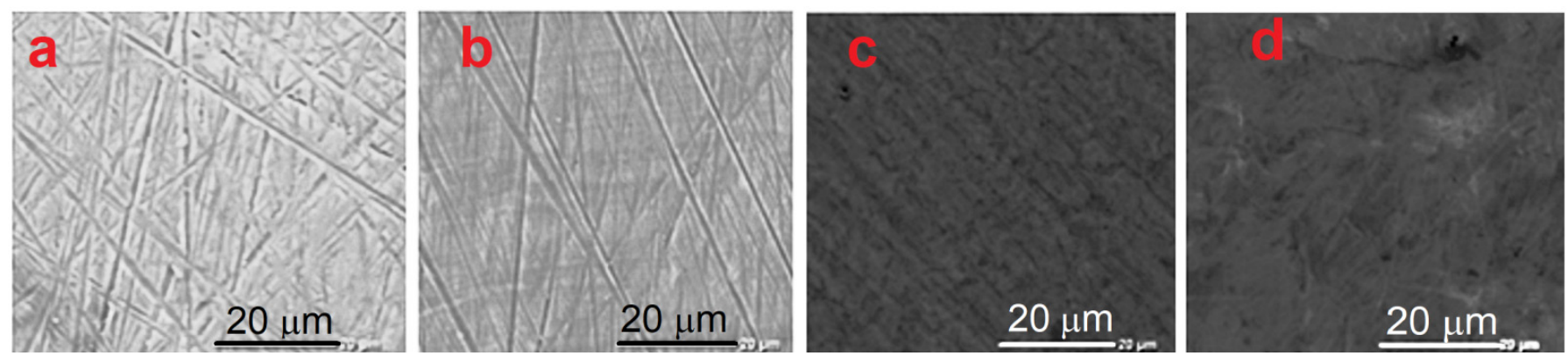

Figure 2. The SEM-images of the 321 steel surfaces: as-received (a), as well as after HIPIB irradiation at the energy densities of (b) 0.6 , (c) 1.0 , and (d) $2.0 \mathrm{~J} / \mathrm{cm}^{2}$.

Roughness $R a$ of the HIPIB irradiated sample surfaces increased by three times (from 20 up to $60 \mathrm{~nm}$ ) with raising the energy density (Figure 3) because of the formation of the crater, which was a characteristic for this surface treatment method $[79,91]$.

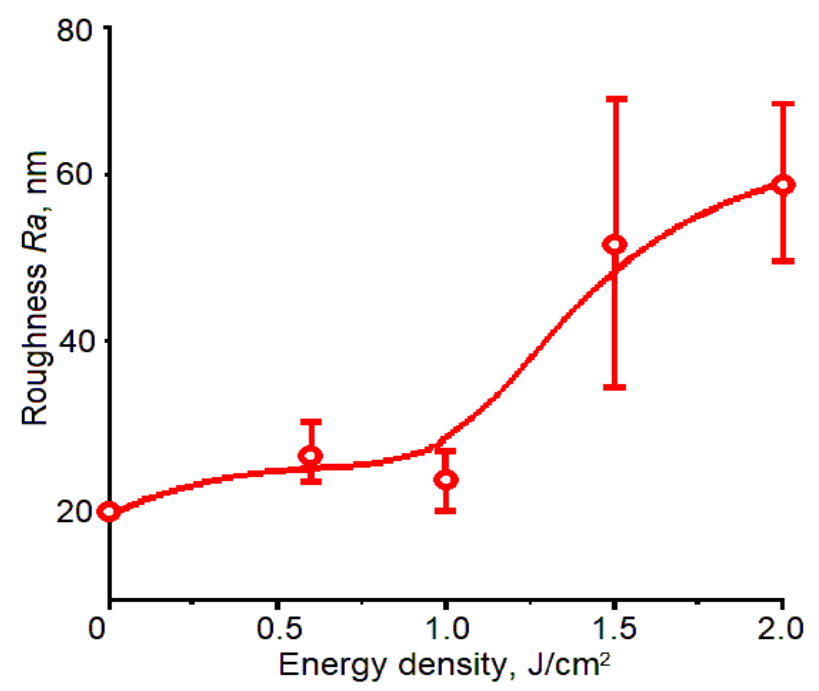

Figure 3. The surface roughness versus energy density.

The results of X-ray diffraction analysis are shown in Figure 4 and Table 2 for both initial and HIPIB irradiated samples. In the initial state, the 321 steel contained two phases: the $\alpha$-Fe and $\gamma$-Fe ones. Modification of the surface layers caused changes in their phase 
composition. With an increase in the energy density, the $\alpha$-Fe phase content reduced with a corresponding increase in the $\gamma$-Fe amount, which was the only one found at $2.0 \mathrm{~J} / \mathrm{cm}^{2}$. Moreover, a decrease in the lattice parameters of both phases was observed with raising the energy density levels (Table 2). Lowering the $\alpha$-Fe lattice parameter indicated the formation of compressive macrostresses in the surface layers under HIPIB irradiation. The $\gamma$-Fe lattice parameter also decreased with an increase in the energy density up to $1.0 \mathrm{~J} / \mathrm{cm}^{2}$ but slightly enhanced (up to $0.3587 \mathrm{~nm}$ ) at 1.5 and $2.0 \mathrm{~J} / \mathrm{cm}^{2}$. It should be noted that microstrains rose much faster in the $\alpha$-Fe phase than in the $\gamma$-Fe one.

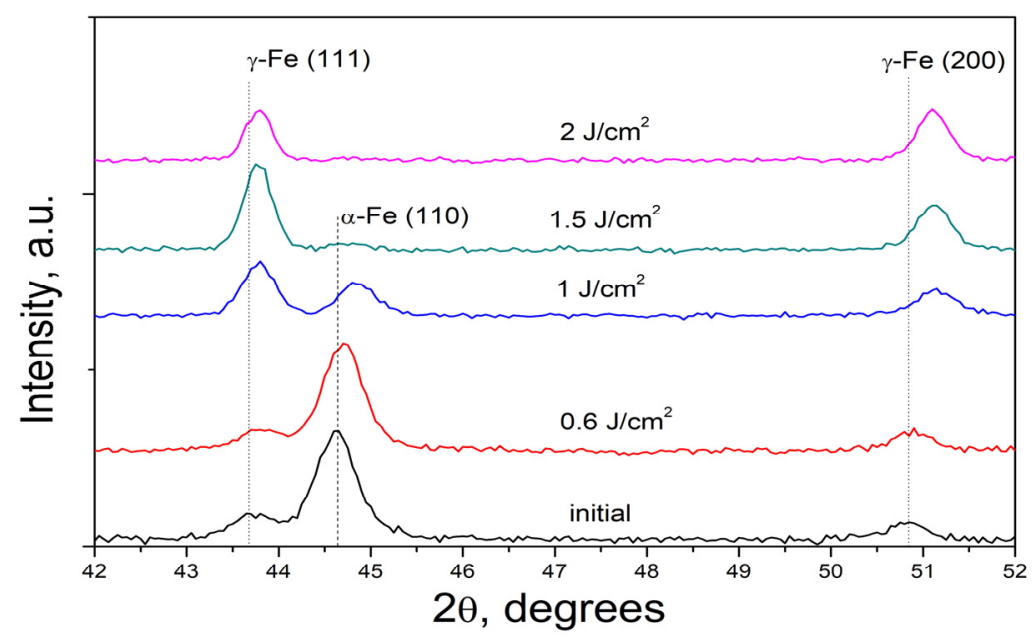

Figure 4. The X-ray diffraction patterns of the surface layers.

Table 2. The lattice parameter, phase composition and microstrains in the surface layers.

\begin{tabular}{|c|c|c|c|c|c|}
\hline \multirow{2}{*}{$\begin{array}{l}\text { HIPIB Energy } \\
\text { Density, J/cm }{ }^{2}\end{array}$} & \multicolumn{2}{|c|}{ Lattice Parameter $a, \mathrm{~nm}$} & \multirow{2}{*}{$\begin{array}{c}\alpha-\mathrm{Fe} / \gamma-\mathrm{Fe} \\
\text { Ratio }\end{array}$} & \multicolumn{2}{|c|}{ Microstrains, \% } \\
\hline & $\alpha-\mathrm{Fe}$ & $\gamma$-Fe & & $\alpha$-Fe & $\gamma$-Fe \\
\hline initial & 0.2873 & 0.3593 & $40 / 60$ & 0.41 & 0.00 \\
\hline 0.6 & 0.2869 & 0.3590 & $41 / 59$ & 0.42 & 0.05 \\
\hline 1.0 & 0.2858 & 0.3585 & $27 / 73$ & 1.00 & 0.10 \\
\hline 1.5 & - & 0.3587 & $2 / 98$ & - & 0.17 \\
\hline 2.0 & - & 0.3587 & $3 / 97$ & - & 0.15 \\
\hline
\end{tabular}

After HIPIB irradiation, the microhardness of the surface layers increased slightly at the minimum studied energy density of $0.6 \mathrm{~J} / \mathrm{cm}^{2}$ and then decreased by $25 \%$ (compared to the initial values) at the maximum level of $2.0 \mathrm{~J} / \mathrm{cm}^{2}$ (Figure 5a). At the same time, the elastic modulus values showed directly opposite dependences (Figure 5b). The most probable reason for this phenomenon was reducing the work-hardening effect for the rolled 321 steel plates upon re-melting.

Significant changes in the energy and chemical activity characteristics of the surface layers were found after HIPIB irradiation. The FSE levels monotonically increased over the entire studied range of the energy densities (Figure 6). At the maximum FSE value, its polar component also reached the highest level, which reflected, among other things, the chemical activity of the surfaces. At the same time, re-melting of the surface layers resulted in an almost complete suppression of the dispersed component, which could have both a positive effect due to decreasing residual stresses at the coating/substrate interfaces and a negative impact on adhesion because of reducing Van der Waals forces. 


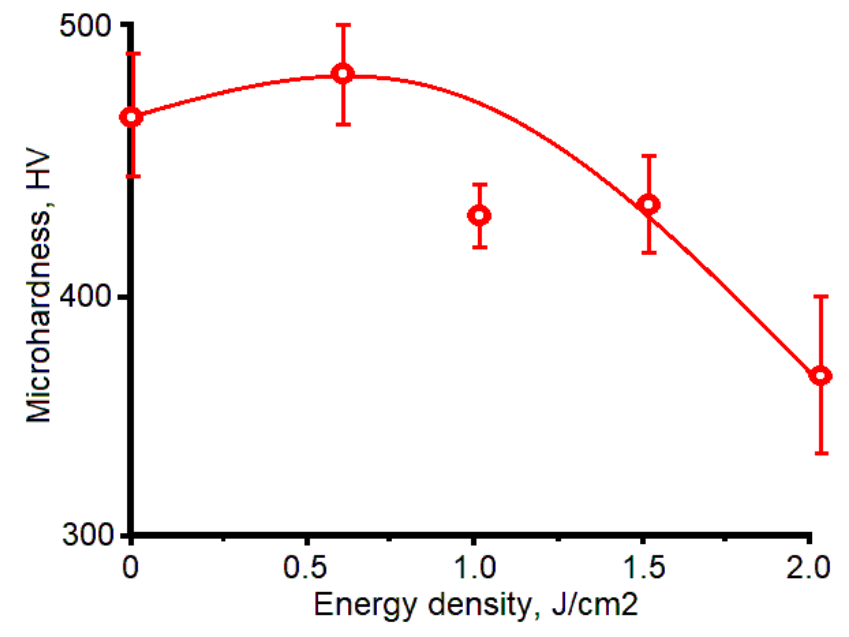

(a)

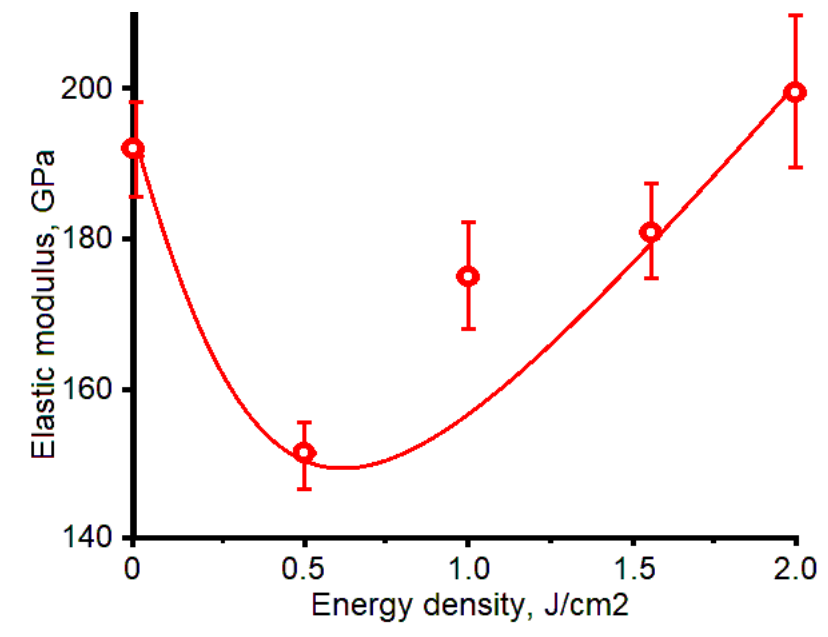

(b)

Figure 5. Microhardness (a) and the elastic modulus (b) of the surface layers versus energy density.

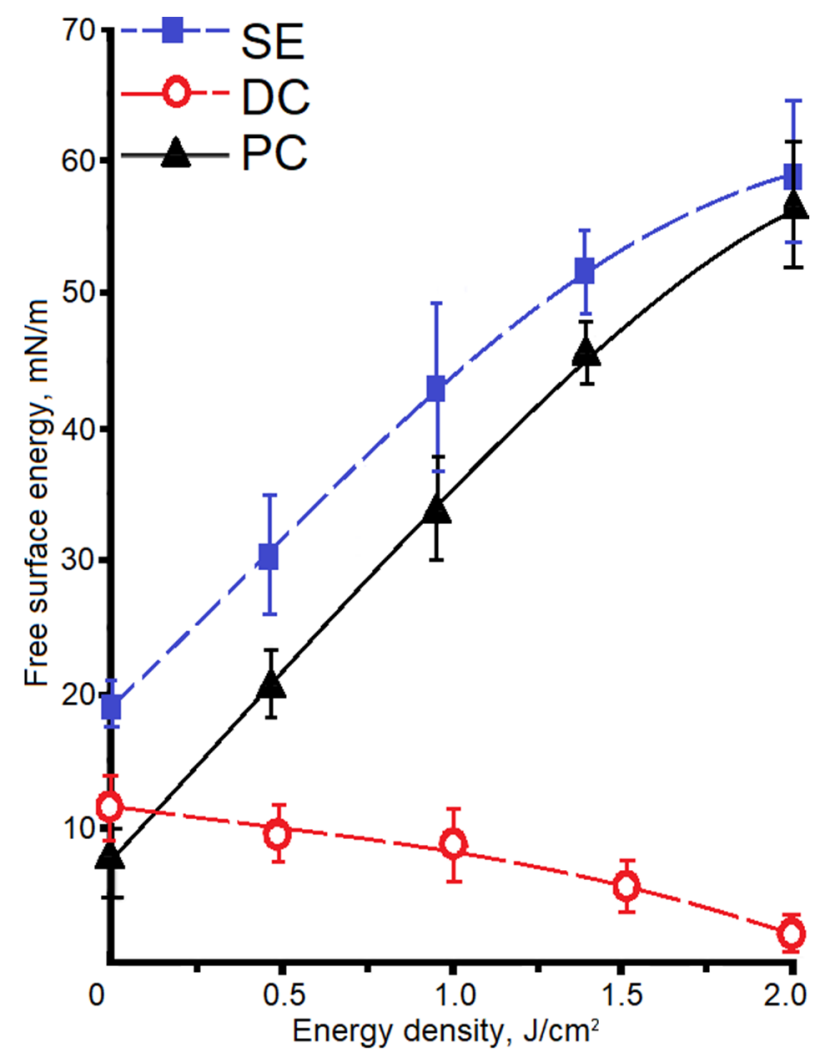

Figure 6. The FSE levels of the surface layers versus energy density (SE-total surface free energy, DC-dispersive component, PC—polar component).

\subsection{The Scratch Test Results of the AlN Coatings on the 321 Steel Substrates}

In order to assess the effect of HIPIB irradiation of the substrates on the tribological behavior of the AlN coatings, scratch tests were carried out, combined with the AE signal processing. In this research method, the AE signal peaks were associated with the initiation and propagation of cracks in the coatings under indenter forces $(F n)$ above limited levels $[32,37,51,87-90]$. The intensity of the AE signal peaks was proportional to (i) the number of formed cracks and (ii) the number of broken interatomic bonds (the fractured coating volume). The scratch test results and images of the sample surfaces with the indenter traces are shown in Figures 7 and 8, respectively. Unfortunately, the tester software did not enable 
any dimension markers to be obtained, but it was possible to proceed from the indenter radius of $100 \mu \mathrm{m}$ when evaluating image sizes.

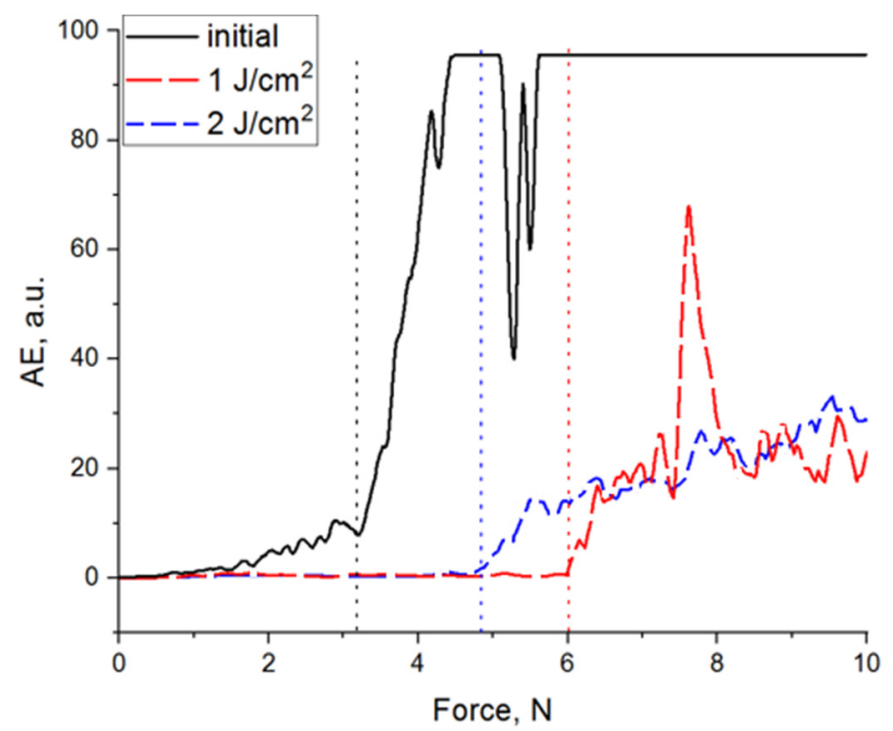

Figure 7. The scratch-test results of the AlN coating on the 321 steel substrates.
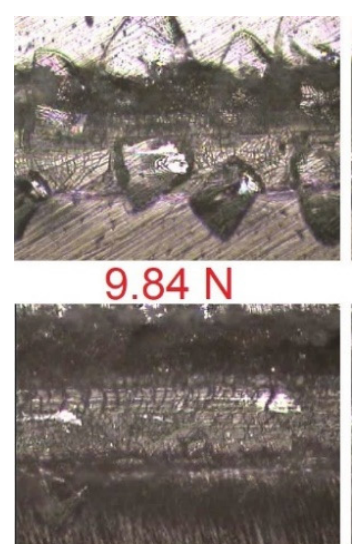

$14.46 \mathrm{~N}$

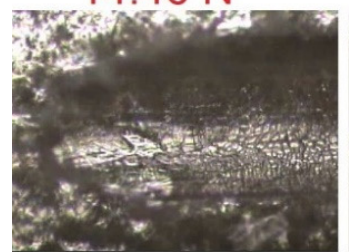

$19.84 \mathrm{~N}$

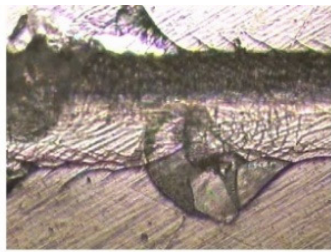

$6.63 \mathrm{~N}$

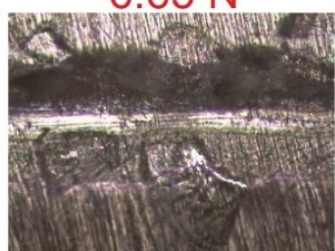

$8.28 \mathrm{~N}$

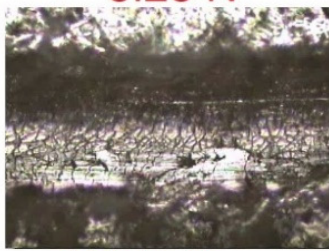

$15.74 \mathrm{~N}$

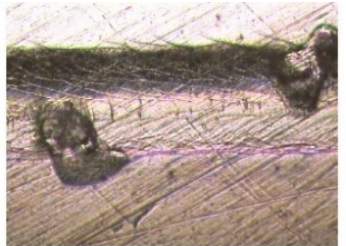

$5.84 \mathrm{~N}$

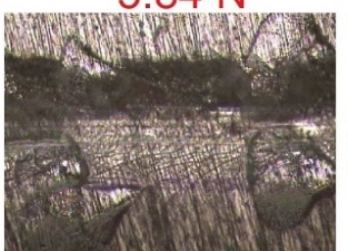

$7.48 \mathrm{~N}$

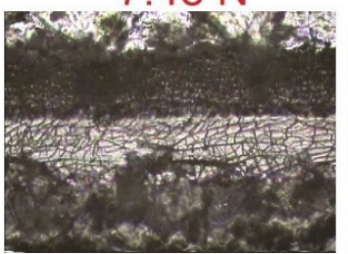

$11.98 \mathrm{~N}$

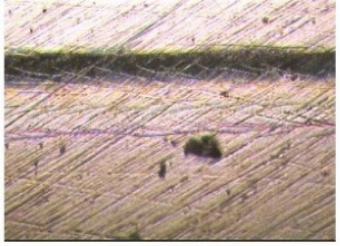

$3.27 \mathrm{~N}$

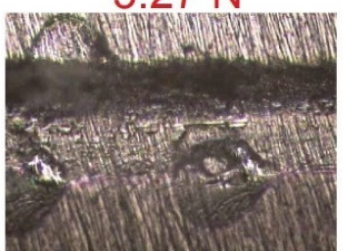

$6.33 \mathrm{~N}$

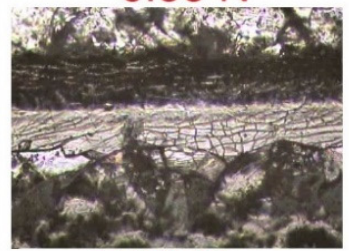

$7.99 \mathrm{~N}$

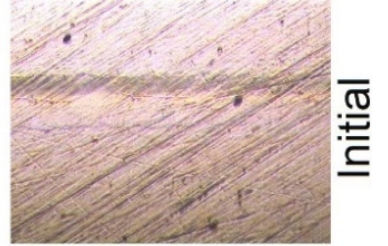

$1.19 \mathrm{~N}$

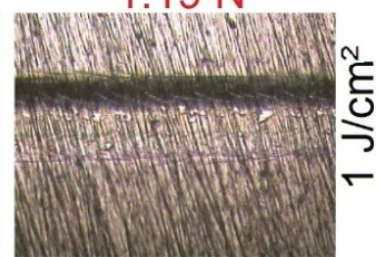

$3.03 \mathrm{~N}$

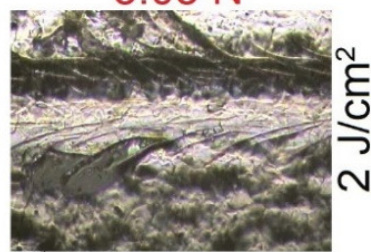

$3.93 \mathrm{~N}$

Figure 8. The sample surfaces after the scratch tests under different indenter forces.

For deposition on the metal substrates, the mode at the temperature of $120{ }^{\circ} \mathrm{C}$ was chosen with minimal resulting tensile stresses on the silicon ones. It was assumed that their adhesion to elastic substrates would be higher than that for coatings with compressive stresses. Moreover, they were minimal in value.

For the coating on the initial substrate, the fracture threshold was 3 N. HIPIB irradiation caused a shift at the beginning of the coating fracture up to 5 and $6 \mathrm{~N}$ at the energy densities of 2.0 and $1.0 \mathrm{~J} / \mathrm{cm}^{2}$, respectively. The lower $F n$ value in the case of $2.0 \mathrm{~J} / \mathrm{cm}^{2}$ could be associated with the decrease in the substrate hardness and, as a consequence, its greater strains under the load. As a result, the AE signal intensity was significantly lower 
for the coatings deposited on the modified substrates, which indicated an increase in the mechanical resistance of the coating/substrate system. Accordingly, the crack initiation threshold could be at least doubled for the studied coating and substrate system due to preliminary HIPIB irradiation.

\section{Discussion}

According to the authors, discussion of the improved scratch test results after HIPIB irradiation should be started with the most probable root causes of this phenomenon. It is known that many factors affected adhesion at the ceramic/metal interfaces, among which the key ones were the microstructure, topography and chemical composition of the surface layers, plastic and elastic properties of both materials, loading conditions, presence of defects and their sizes, as well as residual internal stresses [26-32,92]. All of the above parameters, together with many other ones that have less effect, caused the change in the FSE levels, which were typically considered as a measure of the 'unsatisfied bond energy', arising from the 'broken bonds' exposed on the material surfaces, that affected wetting [93]. This relationship was confirmed, as the scratch test results correlated with the FSE levels (Figures 6 and 7, respectively). However, any scratch tests showed only qualitative patterns. Despite the widespread applications of this method, it was difficult to quantify adhesion because the critical load was affected by many factors such as substrate hardness, coating thickness, interfacial bonding and parameters related to the test conditions. For example, the effect of the indenter radius on adhesion of both $\mathrm{TiN}$ and $\mathrm{CrN}$ coatings deposited on different metal substrates by arc spraying was reported in [94]. The critical load depended on the indenter radius, while groove depths in the coatings were determined only by the sample strain degree and not by the substrate materials. For both coatings, fracture modes were mainly related to their cohesive strength. In addition, the authors of [51] reported that fracture of the WC coating on pure tungsten did not depend on the scratching rate, since its enhancing did not change shapes of forming grooves, but caused earlier initiation of cracks and their higher density, as well as raising the AE signals.

The next nuance that should be discussed is the identification of the factor that had the greatest impact on the increase in the FSE levels of the 321 steel after HIPIB irradiation. As indicated above, the morphology and roughness of the surface layers (Figures 2 and 3, respectively), as well as their phase composition (Figure 4 and Table 2) and the mechanical properties (Figure 5), changed simultaneously.

According to previously published data, there was no clear correlation between surface roughness and coating adhesion. For example, surface roughness minimization was recommended by the authors of $[28,53,57,92]$. However, there were other suggestions, such as high-energy surface processing, that caused its raising. As an instance, ion irradiation cleared the substrate surfaces from most contaminants and broke chains of surface bonds, exposing active centers on which the deposited coatings were covalently bound [66]. The substrate roughening had to result in extremely effective adhesion combined with ion irradiation that activated the interface chemical activity. On some inhomogeneous substrates, ion bombardment caused the formation of rough surfaces, which strengthened the interface formed due to its fracture toughness, as well as its increased clean contact area. At the same time, plasma pre-treatment allowed surfaces of aluminum, copper and AlN ceramics to possess hydrophilic behavior due to removing oxides and impurities, which could enhance the surface reactivity [64]. The adhesion strength of the $\mathrm{Al} / \mathrm{AlN}$ and $\mathrm{Cu} / \mathrm{AlN}$ combinations increased with rising both plasma power and treatment duration. However, the adhesion of titanium and porcelain was not improved by either sandblasting or electric discharge surface processing [61].

Changes in the mechanical properties of the surface layers also had a dual effect. For instance, cracks in ceramics adjacent to substrates typically propagated towards the metal and passed through the interface if it was poorly bonded. In other cases, cracks propagated into a brittle reaction layer or an embrittled intermediate one if the interface was strong [29]. As an example, preliminary sandblasting of the 17-4PH steel substrates before deposition of 
the $\mathrm{Cr}_{3} \mathrm{C}_{2}-\mathrm{NiCr}$ coatings was ambiguous [58]. Despite the positive effect on adhesion due to a change in roughness, the microstructure and mechanical properties of the surface layer were also varied. An increase in hardness at the interface by more than $20 \%$ was observed compared to that in the bulk steel. The influence of the deposition parameters was close to zero in this case. The potential adverse effects of sandblasting were confirmed by a local investigation of an embedded residual alumina particle. An ultra-fine grain microstructure was found associated with a very local increase in hardness $(40 \%$ higher than that for the bulk steel). Cracks initiated from the particle edges and fractures mainly occurred through the surface layer but not at the coating/substrate interface [58]. It should be noted that preliminary sandblasting also resulted in the cracking of glass-ceramic coatings deposited on the 441 stainless steel substrates [59]. Typically, the interface fracture did not occur in the case of high-strength ductile metals firmly bonded to ceramics [29]. In this case, the crack could propagate in the ceramic coatings near the interface, causing plastic metal strains, or cross the interface repeatedly. The results depended on the specific materials, load conditions and interface strength.

According to the concept proposed by the authors of [29], it was difficult to characterize the fracture energy and resistance of the metal/ceramic interfaces because of their different elastic constants and complex stress states. The work of adhesion actually accounted for only a few percent of the total fracture energy of most metal/ceramic interfaces, and the remaining energy was largely dissipated by plastic metal strains. The fracture toughness of the metal/ceramic interfaces could be maximized by forming a strong bond with a high-strength metal that absorbed energy. This concept was confirmed by the authors [67], who investigated the adhesion of the $\mathrm{CrN}_{\mathrm{x}}$ coatings on various types of steel and polycrystalline copper. In the steel cases, two-layer structures formed within the coating, which was more pronounced if the substrate was implanted with metal ions prior to deposition. Four-point bending tests showed plastic strains of the $\mathrm{CrN}_{\mathrm{x}}$ coating deposited on the soft copper substrate, but its brittle delamination from the hard tool steel was observed [67]. Accordingly, the decrease in microhardness and the increase in the elastic modulus of the surface layers due to the change in their phase composition could also have a positive effect on the scratch test results in these studies.

It should also be considered that the best deposition mode estimated from the three investigated ones on the silicon substrates was probably not the optimum for the 321 steel since there could be two types of residual stresses in the coatings [92]. The first type arose from discontinuities formed in the deposition process (their levels could be reduced by an increase in the substrate temperature). Another reason for residual stresses was associated with a mismatch between the thermal expansion coefficients of the substrate and the coating. Levels of such stresses depended on their ratio, as well as the substrate dimensions. Since these characteristics varied for the silicon and 321 steel substrates, resulting residual stresses were also different. In this regard, additional studies (both theoretical and experimental) are required for a more accurate understanding of the essence of these variations. This is one of the most urgent research areas since, for example, residual stresses were the dominant factor affecting the bond strength of the $\mathrm{Si}_{3} \mathrm{~N}_{4}-\mathrm{WC} / \mathrm{TiC} / \mathrm{TaC}$ coatings and nickel substrates [54]. In this case, cracks were initiated near the interface edges and then propagated into the ceramics.

Finally, it could be concluded on the basis of the foregoing that the obtained results were rather primary and needed additional justification both from the point of view of the root causes of this phenomenon and the possibility of their extrapolation to other coatings/substrate systems, as well as irradiation modes and coating methods. Moreover, additional research methods are required for assessing both mechanical and tribological properties, as well as the microstructure of the modified layers, despite their high labor intensity and cost. The authors plan to report such results in their following papers.

\section{Conclusions}

The obtained results enabled the following conclusions to be drawn: 
1. HIPIB irradiation of the 321 steel surfaces caused partial melting of irregularities at the energy densities of 1.0 and $1.5 \mathrm{~J} / \mathrm{cm}^{2}$ but full recrystallization of the surface layer at $2.0 \mathrm{~J} / \mathrm{cm}^{2}$. As a result, roughness $R a$ of the modified surfaces increased by three times (from 20 up to $60 \mathrm{~nm}$ ).

2. With an increase in the energy density, the $\alpha$-Fe phase content in the surface layers reduced with the corresponding increase in the $\gamma$-Fe amount, which was the only one found at $2.0 \mathrm{~J} / \mathrm{cm}^{2}$. The $\gamma$-Fe lattice parameter decreased with an increase in the energy density up to $1.0 \mathrm{~J} / \mathrm{cm}^{2}$ but slightly enhanced (up to $0.3587 \mathrm{~nm}$ ) at 1.5 and $2.0 \mathrm{~J} / \mathrm{cm}^{2}$. Microstrains rose much faster in the $\alpha$-Fe phase than in the $\gamma$-Fe one.

3. After HIPIB irradiation, the microhardness of the surface layers increased slightly at the minimum studied energy density of $0.6 \mathrm{~J} / \mathrm{cm}^{2}$ and then decreased by $25 \% \mathrm{com}$ pared to the initial values, at the maximum level of $2.0 \mathrm{~J} / \mathrm{cm}^{2}$. The elastic modulus values showed directly opposite dependences due to the reduced work-hardening effect.

4. The FSE values and their polar components monotonically increased over the entire studied range of the energy densities, which resulted in the chemical activity of the surfaces. However, suppression of the dispersed component was observed that decreased both residual stresses at the coating/substrate interfaces and Van der Waals forces.

5. During the scratch tests, the fracture threshold was $3 \mathrm{~N}$ for the AlN coating on the initial 321 steel substrate. HIPIB irradiation caused a shift at the beginning of the coating fracture up to 5 and $6 \mathrm{~N}$ at the energy densities of 2.0 and $1.0 \mathrm{~J} / \mathrm{cm}^{2}$, respectively. The lower fracture threshold value in the case of $2.0 \mathrm{~J} / \mathrm{cm}^{2}$ could be associated with the decrease in the substrate hardness and, as a consequence, its greater strains under the load.

Author Contributions: Conceptualization, V.T., V.U., S.P. and G.R.; methodology, V.T., S.P., E.S., V.U. and G.R.; validation, V.T., S.P., V.U., E.S. and G.R.; formal analysis, V.T., S.P., V.U., M.S. and G.R.; investigation, V.T., S.P., E.S. and V.U.; resources, G.R.; data curation, V.T., V.U. and G.R.; writingoriginal draft preparation, V.T., V.U. and M.S.; writing—review and editing, M.S.; visualization, V.T., V.U. and M.S.; supervision, G.R.; project administration, V.T. and G.R.; funding acquisition, G.R. All authors have read and agreed to the published version of the manuscript.

Funding: This research was funded by RFBR and ROSATOM, grant number 20-21-00025.

Institutional Review Board Statement: Not applicable.

Informed Consent Statement: Not applicable.

Data Availability Statement: The original data can be shared by the authors upon individual request.

Conflicts of Interest: The authors declare no conflict of interest. The funders had no role in the design of the study; in the collection, analyses, or interpretation of data; in the writing of the manuscript, or in the decision to publish the results.

\section{References}

1. Rieu, J. Ceramic formation on metallic surfaces (ceramization) for medical applications. Clin. Mater. 1993, 12, 227-235. [CrossRef]

2. Wolfe, D.; Singh, J. Functionally gradient ceramic/metallic coatings for gas turbine components by high-energy beams for high-temperature applications. J. Mater. Sci. 1998, 33, 3677-3692. [CrossRef]

3. Agüero, A. Progress in the development of coatings for protection of new generation steam plant components. Energy Mater. 2008, 3, 35-44. [CrossRef]

4. Mehran, Q.M.; Fazal, M.A.; Bushroa, A.R.; Rubaiee, S. A critical review on physical vapor deposition coatings applied on different engine components. Crit. Rev. Solid State Mater. Sci. 2018, 43, 158-175. [CrossRef]

5. Aouadi, S.M.; Gu, J.; Berman, D. Self-healing ceramic coatings that operate in extreme environments: A review. J. Vac. Sci. Technol. A Vac. Surf. Film. 2020, 38, 050802. [CrossRef]

6. Selvaraj, S.K.; Srinivasan, K.; Deshmukh, J.; Agrawal, D.; Mungilwar, S.; Jagtap, R.; Hu, Y.-C. Performance comparison of advanced ceramic cladding approaches via solid-state and traditional welding processes: A review. Materials 2020, 13, 5805. [CrossRef]

7. Akahoshi, E.; Matsunaga, M.; Kimura, K.; Nakamura, K.; Balden, M.; Hishinuma, Y.; Chikada, T. Corrosion tests of multi-layer ceramic coatings in liquid lithium-lead. Fusion Eng. Design 2020, 160, 111874. [CrossRef] 
8. Wang, H.; Xiao, J.; Wang, H.; Chen, Y.; Yin, X.; Guo, N. Corrosion behavior and surface treatment of cladding materials used in high-temperature lead-bismuth eutectic alloy: A review. Coatings 2021, 11, 364. [CrossRef]

9. Attarzadeh, N.; Molaei, M.; Babaei, K.; Fattah-alhosseini, A. New promising ceramic coatings for corrosion and wear protection of steels: A review. Surf. Interfaces 2021, 23, 100997. [CrossRef]

10. Khatkhatay, F.; Jiao, L.; Jian, J.; Zhang, W.; Jiao, Z.; Gan, J.; Zhang, H.; Zhang, X.; Wang, H. Superior corrosion resistance properties of TiN-based coatings on Zircaloy tubes in supercritical water. J. Nucl. Mater. 2014, 451, 346-351. [CrossRef]

11. Iwamoto, N.; Makino, Y.; Umesaki, N.; Endo, S.; Kobayashi, H. Effect of pretreatments of metals on bond adhesion. In Proceedings of the International Thermal Spraying Conference, Essen, Germany, 2-6 May 1983; DVS-Berichte: Duesseldorf, Germany, 1983; pp. 18-20.

12. Aries, L.; Jalama, L.; Laaouini, A.; Roy, J. Preparation and characterisation of electrolytically deposited ceramic coating on stainless steel. Surf. Eng. 1998, 14, 235-239. [CrossRef]

13. Chen, B.F.; Hwang, J.; Yu, G.P.; Huang, J.H. In situ observation of the cracking behavior of TiN coating on 304 stainless steel subjected to tensile strain. Thin Solid Film. 1999, 352, 173-178. [CrossRef]

14. Ohmura, T.; Matsuoka, S. Evaluation of mechanical properties of ceramic coatings on a metal substrate. Surf. Coat. Technol. 2003, 169-170, 728-731. [CrossRef]

15. Pugal Mani, S.; Srinivasan, A.; Rajendran, N. Effect of nitrides on the corrosion behaviour of 316L SS bipolar plates for Proton Exchange Membrane Fuel Cell (PEMFC). Int. J. Hydrog. Energy 2015, 40, 3359-3369. [CrossRef]

16. Lee, S.H.; Woo, S.P.; Kakati, N.; Lee, Y.N.; Yoon, Y.S. Corrosion and electrical properties of carbon/ceramic multilayer coated on stainless steel bipolar plates. Surf. Coat. Technol. 2016, 303, 162-169. [CrossRef]

17. Omrani, M.; Habibi, M.; Saeed, M.; Birjandi, M. Enhanced electrical conductivity of two layers AlN-TiN coating on SS316L as bipolar plate using plasma focus device. Int. J. Hydrog. Energy 2016, 41, 5028-5036. [CrossRef]

18. Cubillos, G.I.; Bethencourt, M.; Alfonso, J.E.; Rodríguez-Castellón, E.; Romero, E. Porosity reduction in new thin films of ceramic coatings on stainless steel by annealing at reduced pressure. Metall. Mater. Trans. A 2018, 49, 5858-5870. [CrossRef]

19. Yi, P.; Zhu, L.; Dong, C.; Xiao, K. Corrosion and interfacial contact resistance of 316L stainless steel coated with magnetron sputtered $\mathrm{ZrN}$ and $\mathrm{TiN}$ in the simulated cathodic environment of a proton-exchange membrane fuel cell. Surf. Coat. Technol. 2019, 363, 198-202. [CrossRef]

20. Huang, J.-H.; Kuo, K.-L.; Yu, G.-P. Oxidation behavior and corrosion resistance of vacuum annealed ZrN-coated stainless steel. Surf. Coat. Technol. 2019, 358, 308-319. [CrossRef]

21. Sharma, G.S.; Sugavaneswaran, M.; Vijayalakshmi, U.; Prakash, R. Influence of $\gamma$-alumina coating on surface properties of direct metal laser sintered 316L stainless steel. Ceram. Int. 2019, 45, 13456-13463. [CrossRef]

22. Andrei, V.A.; Radulescu, C.; Malinovschi, V.; Marin, A.; Coaca, E.; Mihalache, M.; Mihailescu, C.N.; Dulama, I.D.; Teodorescu, S.; Bucurica, I.A. Aluminum oxide ceramic coatings on 316L austenitic steel obtained by plasma electrolysis oxidation using a pulsed unipolar power supply. Coatings 2020, 10, 318. [CrossRef]

23. Zaborowska, A.; Kurpaska, Ł.; Wyszkowska, E.; Clozel, M.; Vanazzi, M.; Di Fonzo, F.; Turek, M.; Jóźwik, I.; Kosińska, A.; Jagielski, J. Influence of ion irradiation on the nanomechanical properties of thin alumina coatings deposited on 316L SS by PLD. Surf. Coat. Technol. 2020, 386, 125491. [CrossRef]

24. Prashar, G.; Vasudev, H. High temperature erosion behavior of plasma sprayed Al2O3 coating on AISI-304 stainless steel. World J. Eng. 2021. [CrossRef]

25. Leng, Y.; Ming, P.; Yang, D.; Zhang, C. Stainless steel bipolar plates for proton exchange membrane fuel cells: Materials, flow channel design and forming processes. J. Power Sources 2020, 451, 227783. [CrossRef]

26. Buckley, D.H. The role of material properties in adhesion. In Proceedings of the Fall Meeting of the Materials Research Society, Boston, MA, USA, 26-30 November 1984; pp. 1-26.

27. Finnis, M.W. Metal-ceramic cohesion and the image interaction. Acta Metall. Mater. 1992, 40, S25-S37. [CrossRef]

28. Howe, J.M. Bonding, structure, and properties of metal/ceramic interfaces. Part 1. Chemical bonding, chemical reaction, and interfacial structure. Int. Mater. Rev. 1993, 38, 233-256. [CrossRef]

29. Howe, J.M. Bonding, structure, and properties of metal/ceramic interfaces. Part 2. Interface fracture behaviour and property measurement. Int. Mater. Rev. 1993, 38, 257-271. [CrossRef]

30. Finnis, M.W. The theory of metal-ceramic interfaces. J. Phys. Condens. Matter 1996, 8, 5811-5836. [CrossRef]

31. Li, J.-G. Energetics of metal/ceramic interfaces, metal-semiconductor Schottky contacts, and their relationship. Mater. Chem. Phys. 1997, 47, 126-145. [CrossRef]

32. Liu, L.M.; Wang, S.Q.; Ye, H.Q. Atomic and electronic structures of the lattice mismatched metal-ceramic interface. J. Phys. Condens. Matter 2004, 16, 5781-5790. [CrossRef]

33. Gerberich, W.W.; Cordill, M.J. Physics of adhesion. Rep. Prog. Phys. 2006, 69, 2157-2203. [CrossRef]

34. Siddiq, A.; Schmauder, S.; Ruehle, M. Niobium/alumina bicrystal interface fracture: A theoretical interlink between local adhesion capacity and macroscopic fracture energies. Eng. Fract. Mech. 2008, 75, 2320-2332. [CrossRef]

35. Poklad, A.; Klemm, V.; Schreiber, G.; Wustefeld, C.; Rafaja, D. Microstructure investigation of the PVD thin films of TRIP steels. Solid State Phenom. 2010, 160, 273-279. [CrossRef] 
36. Siddiq, A.; Schmauder, S. Multiscale simulation of metal/ceramic interface fracture. In Proceedings of the IUTAM Symposium on Multi-Functional Material Structures and Systems, Bangalore, India, 10-12 December 2008; Dattaguru, B., Gopalakrishnan, S., Aatre, V., Eds.; Springer: Dordrecht, Germany, 2010; Volume 19, pp. 343-355. [CrossRef]

37. Miculescu, M.; Bane, M.; Miculescu, F.; Ciocan, L.T.; Preda, O.; Antoniac, I. A study on metal-ceramic interface on metal base dental alloys. Key Eng. Mater. 2014, 638, 14-19. [CrossRef]

38. Feldbauer, G.; Wolloch, M.; Bedolla, P.O.; Mohn, P.; Redinger, J.; Vernes, A. Adhesion and material transfer between contacting Al and TiN surfaces from first principles. Phys. Rev. B Condens. Matter Mater. Phys. 2015, 91, 165413. [CrossRef]

39. $\mathrm{Mu}$, Y.; Zhang, X.; Hutchinson, J.W.; Meng, W.J. Measuring critical stress for shear failure of interfacial regions in coating/interlayer/substrate systems through a micro-pillar testing protocol. J. Mater. Res. 2017, 32, 1421-1431. [CrossRef]

40. Lin, Z.; Peng, X.; Fu, T.; Zhao, Y.; Feng, C.; Huang, C.; Wang, Z. Atomic structures and electronic properties of interfaces between aluminum and carbides/nitrides: A first-principles study. Phys. E Low-Dimens. Syst. Nanostruct. 2017, 89, 15-20. [CrossRef]

41. Zhang, X.; Zhang, B.; Mu, Y.; Shao, S.; Wick, C.D.; Ramachandran, B.R.; Meng, W.J. Mechanical failure of metal/ceramic interfacial regions under shear loading. Acta Mater. 2017, 138, 224-236. [CrossRef]

42. Iwasaki, T. Efficient optimum design of metal with strong adhesion to ceramics with a combination of orthogonal array and response-surface method. J. Soc. Mater. Sci. 2018, 67, 803-810. [CrossRef]

43. Zhang, X.; Mu, Y.; Dodaran, M.; Shao, S.; Moldovan, D.; Meng, W.J. Mechanical failure of CrN/Cu/CrN interfacial regions under tensile loading. Acta Mater. 2018, 160,1-13. [CrossRef]

44. Liu, X.; Dong, H.; Lv, X.; Hu, N.; Wen, L.; Yang, Z. First-principle study of interfacial properties between $\gamma$-TiAl and TiC, VN. Mol. Simul. 2019, 45, 50-57. [CrossRef]

45. Mohammad Miraz, A.S.; Sun, S.; Shao, S.; Meng, W.J.; Ramachandran, B.R.; Wick, C.D. Computational study of metal/ceramic interfacial adhesion and barriers to shear displacement. Comput. Mater. Sci. 2019, 168, 104-115. [CrossRef]

46. Mei, Z.-G.; Bhattacharya, S.; Yacout, A.M. Adhesion of $\mathrm{ZrN}$ and $\mathrm{Al}_{2} \mathrm{O}_{3}$ coatings on $\mathrm{U}$ metal from first-principles. Appl. Surf. Sci. 2019, 473, 121-126. [CrossRef]

47. Guan, X.; Wang, Y.; Xue, Q. Effects of constituent layers and interfaces on the mechanical and tribological properties of metal (Cr, $\mathrm{Zr})$ /ceramic (CrN, ZrN) multilayer systems. Appl. Surf. Sci. 2020, 502, 144305. [CrossRef]

48. Li, R.; Chen, Q.; Zhang, Z.; Ouyang, L.; Zhang, Y.; Nie, B.; Ding, Y. Revealing the atomic-scale structure and the fracture mechanism of the $\alpha-\mathrm{Al}_{2} \mathrm{O}_{3} / \gamma$-Fe ceramic-metal interface. J. Alloy. Compd. 2021, 885, 161163. [CrossRef]

49. Miraz, A.S.M.; Meng, W.J.; Ramachandran, B.R.; Wick, C.D. Computational observation of the strengthening of Cu/TiN metal/ceramic interfaces by sub-nanometer interlayers and dopants. Appl. Surf. Sci. 2021, 554, 149562. [CrossRef]

50. Imbriglio, S.I.; Chromik, R.R. Factors affecting adhesion in metal/ceramic interfaces created by cold spray. J. Therm. Spray Technol. 2021. [CrossRef]

51. Zhao, Z.; Liu, F.; Cao, L.; Du, Y.; Li, B.; Li, J.; Xu, Y. Investigation of indentation response, scratch resistance, and wear behavior of tungsten carbide coatings fabricated by two-step interstitial carburization on tungsten. Ceram. Int. 2021. [CrossRef]

52. Lyubimov, V.V.; Voevodin, A.A.; Spassky, S.E.; Yerokhin, A.L. Stress analysis and failure possibility assessment of multilayer physically vapour deposited coatings. Thin Solid Film. 1992, 207, 117-125. [CrossRef]

53. Skalka, P.; Slámečka, K.; Pokluda, J.; Čelko, L. Finite element simulation of stresses in a plasma-sprayed thermal barrier coating with a crack at the TGO/bond-coat interface. Surf. Coat. Technol. 2018, 337, 321-334. [CrossRef]

54. Muraoka, S.; Tateno, M. Dependence of bonding strength and variations in residual stress on interface wedge angles and bonding temperature conditions. MRS Adv. 2020, 5, 1765-1774. [CrossRef]

55. Mehboob, G.; Liu, M.-J.; Xu, T.; Hussain, S.; Mehboob, G.; Tahir, A. A review on failure mechanism of thermal barrier coatings and strategies to extend their lifetime. Ceram. Int. 2020, 46, 8497-8521. [CrossRef]

56. Tabor, D. Future directions of research in adhesion and friction. In Proceedings of the Tribology International Conference, Cleveland, OH, USA, 18-21 April 1983; NASA: Washington, DC, USA, 1984; Volume 2, pp. 119-142.

57. Takadoum, J.; Houmid Bennani, H. Influence of substrate roughness and coating thickness on adhesion, friction and wear of TiN films. Surf. Coat. Technol. 1997, 96, 272-282. [CrossRef]

58. Giouse, J.-B.; White, K.; Tromas, C. Nanoindentation characterization of the surface mechanical properties of a 17-4PH stainless steel substrate treated with grit blasting and coated with a $\mathrm{Cr}_{3} \mathrm{C}_{2}-\mathrm{NiCr}$ coating. Surf. Coat. Technol. 2019, 368, 119-125. [CrossRef]

59. Parchovianský, M.; Parchovianská, I.; Švančárek, P.; Motz, G.; Galusek, D. PDC glass / ceramic coatings applied to differently pretreated AISI441 stainless steel substrates. Materials 2020, 13, 629. [CrossRef]

60. Inan, Ö.; Acar, A.; Halkaci, S. Effects of sandblasting and electrical discharge machining on porcelain adherence to cast and machined commercially pure titanium. J. Biomed. Mater. Res. Part B Appl. Biomater. 2006, 78, 393-400. [CrossRef]

61. Troia, M.G., Jr.; Henriques, G.E.P.; Mesquita, M.F.; Fragoso, W.S. The effect of surface modifications on titanium to enable titanium-porcelain bonding. Dent. Mater. 2008, 24, 28-33. [CrossRef]

62. Mittal, K.L.; Lei, W.-S. (Eds.) Laser Technology: Applications in Adhesion and Related Areas; Scrivener Publishing: Beverly, MA, USA, 2018. [CrossRef]

63. Kromer, R.; Danlos, Y.; Aubignat, E.; Verdy, C.; Costil, S. Coating deposition and adhesion enhancements by laser surface texturing-metallic particles on different classes of substrates in cold spraying process. Mater. Manuf. Process. 2017, 32, 1642-1652. [CrossRef] 
64. Jang, K.-B.; Mhin, S.; Lim, S.-C.; Song, Y.-S.; Lee, K.-H.; Park, S.-K.; Moon, K.-I.; Lee, S.H.; Hyun, S.-K. Room temperature bonding on interface between metal and ceramic. J. Electron. Mater. 2019, 48, 72-78. [CrossRef]

65. Legg, K.O. Surface engineering with ion-assisted coatings. Nucl. Instrum. Methods Phys. Res. B 1987, 24-25, 565-567. [CrossRef]

66. Baglin, J.E.E. Thin film bonding using ion beam techniques-A review. IBM J. Res. Dev. 1994, 38, 413-422. [CrossRef]

67. Escobar Galindo, R.; van Veen, A.; Schut, H.; Janssen, G.C.A.M.; Hoy, R.; de Hosson, J.T.M. Adhesion behaviour of CrNx coatings on pre-treated metal substrates studied in situ by PBA and ESEM after annealing. Surf. Coat. Technol. 2005, 199, 57-65. [CrossRef]

68. Remnev, G.E.; Isakov, I.F.; Opekounov, M.S.; Matvienko, V.M.; Ryzhkov, V.A.; Struts, V.K.; Grushin, I.I.; Zakoutayev, A.N.; Potyomkin, A.V.; Tarbokov, V.A.; et al. High intensity pulsed ion beam sources and their industrial applications. Surf. Coat. Technol. 1999, 114, 206-212. [CrossRef]

69. Remnev, G.E.; Tarbokov, V.A. Increasing the durability of carbide tools by pretreatment with a powerful ion beam and deposition of titanium nitride coating. Phys. Mesomech. 2004, 7, 329-332. (In Russian)

70. Liu, X.; Mei, X.; Qiang, J.; Remnev, G.E.; Wang, Y. Effects on structure and properties of $\mathrm{Zr}_{55} \mathrm{Al}_{10} \mathrm{Cu}_{30} \mathrm{Ni}_{5}$ metallic glass irradiated by high intensity pulsed ion beam. Appl. Surf. Sci. 2014, 313, 911-917. [CrossRef]

71. Ma, X.; Zhang, G.; Wang, G.; Zhu, G.; Zhou, W.; Wang, J.; Sun, B. Surface morphology, microstructure and properties of as-cast AZ31 magnesium alloy irradiated by high intensity pulsed ion beams. Appl. Surf. Sci. 2014, 311, 567-573. [CrossRef]

72. Li, P.; Zou, Y.; Zhang, Z.P. Influence of high-intensity pulsed ion beam irradiation energy on magnesium alloy surface modification. Vacuum 2015, 117, 8-11. [CrossRef]

73. Lei, M.K.; Zhu, X.P.; Li, Y.P.; Guo, D.M. Significance of surface integrity on high-performance manufacturing by surface modification. Int. J. Adv. Manuf. Technol. 2016, 82, 1831-1842. [CrossRef]

74. Mei, X.; Zhang, X.; Liu, X.; Wang, Y. Effect on structure and mechanical property of tungsten irradiated by high intensity pulsed ion beam. Nucl. Instrum. Methods Phys. Res. Sect. B Beam Interact. Mater. At. 2017, 406, 697-702. [CrossRef]

75. Han, X.G.; Lv, J.F.; Chen, Y.Z.; Shan, Y.C.; Xu, J.J. Influence of irradiation intensity on corrosion properties of microarc oxidation film on AZ31 magnesium alloy with HIPIB. Anti-Corrosion Methods Mater. 2019, 66, 418-424. [CrossRef]

76. Nazipov, R.A.; Batalov, R.I.; Bayazitov, R.M.; Novikov, H.A.; Shustov, V.A.; Dulov, E.N. High-intensity pulsed ion beam treatment of amorphous iron-based metal alloy. J. Phys Conf. Ser. 2020, 1588, 012039. [CrossRef]

77. Zou, H.; Zhang, L.; Guan, T.; Zhang, X.; Remnev, G.E.; Pavlov, S.K.; Wang, Y.; Mei, X. Effect on mechanics properties and microstructure of molybdenum by high intensity pulsed ion beam irradiation. Surf. Coat. Technol. 2020, 384, 125333. [CrossRef]

78. Slobodyan, M.S.; Pavlov, S.K.; Remnev, G.E. Corrosion and high-temperature steam oxidation of E110 alloy and its laser welds after ion irradiation. Corros. Sci. 2019, 152, 60-74. [CrossRef]

79. Zhong, H.; Zhang, J.; Shen, J.; Liang, G.; Zhang, S.; Xu, M.; Yu, X.; Yan, S.; Remnev, G.E.; Le, X. Dynamic mechanism of crater formation induced by inclusion during intense pulsed ion beam irradiation. Vacuum 2020, 179, 109541. [CrossRef]

80. Zhidkov, M.V.; Gazizova, M.Y.; Ligachev, A.E.; Pavlov, S.K.; Remnev, G.E. Structure and corrosion properties of stainless steel after high-power ion beam processing. IOP Conf. Ser. Mater. Sci. Eng. 2021, 1014, 012061. [CrossRef]

81. RussianGost. Russian State Standard GOST 58175-2014 Stainless Steels and Corrosion Resisting, Heat-resisting and Creep Resisting Alloys. Grades; RussianGost: Moscow, Russia, 2014. (In Russian)

82. Davis, J.R. ASM Specialty Handbook—Stainless Steels; ASM International: Materials Park, OH, USA, 1994.

83. Panda, P.; Ramaseshan, R.; Ravi, N.; Mangamma, G.; Jose, F.; Dash, S.; Suzuki, K.; Suematsu, H. Reduction of residual stress in AlN thin films synthesized by magnetron sputtering technique. Mater. Chem. Phys. 2017, 200, 78-84. [CrossRef]

84. Stoney, G.G. The tension of metallic films deposited by electrolysis. Proc. R. Soc. Lond. A 1909, 82, $172-175$.

85. Hopcroft, M.A.; Nix, W.D.; Kenny, T.W. What is the Young's Modulus of Silicon? J. Microelectromech. Syst. 2010, 19, 229-238. [CrossRef]

86. Klug, H.P.; Alexander, L.E. X-ray Diffraction Procedures; John Wiley \& Sons Inc.: Hoboken, NJ, USA, 1974.

87. Attar, F.; Ericsson, T. Adhesion evaluation of metallic and ceramic coatings during straining of a steel substrate: Flaking and crack behavior. Scand. J. Metall. 1994, 23, 94-102.

88. Hadef, Z.; Doghmane, A.; Kamli, K. Acoustical investigation of adhesion in liquid metal-ceramic interfaces. Metallofiz. Noveishie Tekhnologii 2018, 40, 955-965. [CrossRef]

89. Paredes, V.I.O.; Gómez, M.P.; Dócimo, L.; Nieva, N.; Pumarega, M.I.L. Analysis of acoustic emission waveform signals produced in test on ceramo-metallics interfaces. Rev. Mater. 2018, 23, e12122. [CrossRef]

90. Kamli, K.; Hadef, Z.; Gacem, A.; Houaidji, N. Prediction of adhesion energy terms in metal/ceramic systems by using acoustic parameters. Metallofiz. Noveishie Tekhnologii 2020, 42, 717-730. [CrossRef]

91. Slobodyan, M. High-energy surface processing of zirconium alloys for fuel claddings of water-cooled nuclear reactors. Nucl. Eng. Des. 2021, 382, 111364. [CrossRef]

92. Martin, P.M. Handbook Deposition Technologies for Film Coatings; Elsevier: Amsterdam, The Netherlands, 2010.

93. Gentleman, M.M.; Gentleman, E. The role of surface free energy in osteoblast-biomaterial interactions. Int. Mater. Rev. 2014, 59, 417-429. [CrossRef]

94. Ichimura, H.; Ishii, Y. Effects of indenter radius on the critical load in scratch testing. Surf. Coat. Technol. 2003, 165, 1-7. [CrossRef] 